\title{
Nonequilibrium Sulfur Capture \& Retention in An Air Cooled Slagging Coal Combustor
}

\author{
Quarterly Report \\ October 1 - December 31, 1997
}

\section{By \\ Bert Zauderer}

Work Performed Under Contract No.: DE-AC22-95PC95102

For

U.S. Department of Energy

Office of Fossil Energy

Federal Energy Technology Center

P.O. Box 880

Morgantown, West Virginia 26507-0880

By

Coal Tech Corp.

P. O. Box 154

Merion Station, Pennsylvania 19066 


\section{Disclaimer}

This report was prepared as an account of work sponsored by an agency of the United States Government. Neither the United States Government nor any agency thereof, nor any of their employees, makes any warranty, express or implied, or assumes any legal liability or responsibility for the accuracy, completeness, or usefulness of any information, apparatus, product, or process disclosed, or represents that its use would not infringe privately owned rights. Reference herein to any specific commercial product, process, or service by trade

name, trademark, manufacturer, or otherwise does not necessarily constitute or imply its endorsement, recommendation, or favoring by the United States Government or any agency thereof. The views and opinions of authors expressed herein do not necessarily state or reflect those of the United States Government or any agency thereof. 


\section{"NONEQUILIBRIUM SULFUR CAPTURE \& RETENTION IN AN AIR COOLED SLAGGING COAL COMBUSTOR}

\section{Ninth Quarterly Technical Progress Report-}

DOE Contract No:: DE-AC22-95PC95102--09

Contract Period of Performance: 9/14/95 to 9/13/98

Period Covered by Report: October 1,1997 to December 31,1997

Contractor: Coal Tech Corp.

P.O. Box 154, Merion Station, PA 19066

Principal Investigator: Dr. Bert Zauderer， Phone No.(610) 667-0442

Date Submitted: April 21, 1998

\section{Prepared for}

FETC Project Manager: Arun Bose

Federal Energy Technology Center

U.S. Department of Energy

P.O. Box 10940

Pittsburgh, PA 15236 


\begin{abstract}
Calcium oxide injected in a slagging combustor reacts with the sulfur from coal combustion to form sulfur-bearing particles, which are deposited on the liquid slag layer on the combustor wall. Due to the low solubility of sulfur in slag, it must be rapidly drained from the combustor to limit sulfur gas re-evolution. Analysis indicated that slag mass flow rates in excess of $400 \mathrm{lb} / \mathrm{hr}$ should limit sulfur re-evolution. The objective of this 36 month project was to perform a series of tests to determine the factors that control the retention of the sulfur in the slag. 19 days of testing were completed prior to 9/30/97. In the present quarterly reporting period ending 12/31/97, 13 tests days were completed on co-firing coal and a high ash, rice husk biomass, which was selected to produce a high slag flow rate. Most of the test effort focussed on developing methods for feeding the very low density rice husks into combustor. Various levels of mineral matter from coal ash, rice husk ash, calcium sulfate, and calcium oxide was injected in the combustor during these 13 tests. The peak mineral matter, injection rate was $592 \mathrm{lb} / \mathrm{hr}$ for a period of about one-hour. No significant sulfur concentration was measured in the slag removed from the combustor. This may be due to the brief test duration, and longer duration tests are planned for the next quarter. The two major accomplishments in this quarter are the successful co-firing of coal and biomass in the slagging combustor. This is a major technical milestone due to its application to greenhouse gas emission reduction. It was not in the original project plan. Also, the total of 31 test days completed by $12 / 31 / 97$ is double the number originally planned.
\end{abstract}




\section{TABLE OF CONTENTS}

ABSTRACT

1. EXECUTIVE SUMMARY

2. RESULTS AND DISCUSSION

2.1 PROJECT DESCRIPTION

2.1.1. Objectives

2.1.2. Technical Approach

2.1.2.1. Overview of the Work

2.1.2.2. Task Description

2.2. PROJECT STATUS

2.2.1. Effort of the Present Quarter

3. CONCLUSIONS

3.1. EFFORT OF THE NEXT QUARTER
PAGE

ii

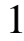

3

3

3

3

3

4

7

7

11

11 


\section{EXECUTIVE SUMMARY}

The objective of this 36 month project is to determine the degree of sulfur retention in slag in a full scale cyclone coal combustor with sulfur capture by calcium oxide sorbent injection into the combustor. This sulfur capture process consists of two steps: Capture of sulfur with calcined calcium oxide followed by impact of the reacted sulfur-calcium particles on the liquid slag lining the combustor. The sulfur bearing slag must be removed within several minutes from the combustor to prevent re-evolution of the sulfur from the slag. To accomplish this requires slag mass flow rates in the range of several $100 \mathrm{lb} / \mathrm{hr}$, and preferably over $400 \mathrm{lb} / \mathrm{hr}$. To study this two step process in the combustor, two groups of tests were implemented. In the first group, calcium sulfate in the form of gypsum, or plaster of Paris, was injected in the combustor to determine sulfur evolution from slag. In the second group, the entire process was tested with limestone and/or calcium hydrate injected into the combustor.

This original planned effort was to consist of a series of up to 16 parametric tests in a 20 MMBtu/hr slagging, air-cooled, cyclone combustor. The originally planned tests were completed in by June 30,1997 . In this original series, high slag flow rates were achieved by using a limited supply of high ash (37\%) Indian coal. In one of these Indian coal tests, a record $20 \%$ of the sulfur injected in the form of gypsum was retained in the slag. This was double the concentration measured in a decade of prior tests in the $20 \mathrm{MMBtu} / \mathrm{hr}$ combustor. However, a subsequent test with the last remaining Indian coal yielded only $5.8 \%$ sulfur in the slag. One possible explanation for this difference was the limited test duration, especially in the latter Indian coal tests.

Consequently, the focus of the effort in the next period, ending September 30,1997, was to secure a source of very high ash ( $>30 \%$ ) coal. No acceptable supply could be found. Consequently, the focus on the present quarterly reporting period, ending 12/31/97, was shifted to co-firing conventional bituminous coal was a high ash biomass. Specifically, rice husk was used, which has a high $15 \%$ to $20 \%$ ash concentration and a higher heating value (HHV) of 6,500 Btu/lb. In addition, a supply of rice husk char-ash was secured. It consists of $70 \%$ ash, $30 \%$ carbon, with a HHV of 3,800 Btu/lb. A total of 13 test days were implemented with the rice husks in this reporting period. Since the bulk density of rice husks is $20 \%$ of pulverized coal, and the rice husk ash is $40 \%$ as dense as coal, the bulk of the effort in these tests was devoted to developing methods for feeding them into the combustor.

To demonstrate the nature of the problem, each section of the combustor's pulverized coal feed system was designed for a capacity of $1,000 \mathrm{lb} / \mathrm{hr}$. This converts into a nominal capacity of $200 \mathrm{lb} / \mathrm{hr}$ for the lower bulk density, rice husks. By various modifications the rice husk feed rate was increased to $310 \mathrm{lb} / \mathrm{hr}$ and that of the twice as dense rice husk, char-ash to $584 \mathrm{lb} / \mathrm{hr}$.

Further development testing in the January-March 1998 quarterly reporting period has resulted in a tripling of the rice husk feed rate to $800 \mathrm{lb} / \mathrm{hr}$. This is four times the original design capacity of $200 \mathrm{lb} / \mathrm{hr}$, and 2.6 times the maximum achieved in the present reporting period. This result is of major importance because co-firing of coal with biomass has much broader applications, such as greenhouse gas emission reduction, than sulfur retention in slag. 
Combustion efficiency and slag flow during co-firing of coal and rice husks or rice husk, ash-char was the same, or somewhat better, as with coal only.

To test sulfur retention in slag, granular gypsum was injected into the combustor with the rice husks and coal. However, this form of gypsum proved unsuitable for feeding and the test was terminated. In a subsequent test, pulverized coal, rice husks, pulverized limestone, and pulverized gypsum was injected into the combustor at a combined mineral matter feed rate of $592 \mathrm{lb} . / \mathrm{hr}$. While excellent combustion efficiency and slag flow was obtained, negligible sulfur reported to the slag. This may have been due to short duration of the injection period, about one-hour. It could also have been due to the different physical structure of this co-fired slag from conventional coal slag.

Further tests on co-firing of coal and rice husk biomass are planned for the next (JanuaryMarch 1998) quarter. However, further testing will be very limited due to resource limitations for this project. The significant accomplishments to date are:

- Implementation of 31 test days versus the originally planned 16, all within the original resource allocation.

- Achievement of $20 \%$ sulfur retention in slag in the high (37\%) ash Indian coal.

- Successful co-firing of coal with rice husk biomass under slag flow conditions suitable for high sulfur retention in slag.

- Implementation of the sulfur in slag retention tests under conditions duplicating commercial slagging combustor operation.

- Determination that high slag mass flow rates are a necessary but insufficient requirement for high sulfur retention in slag. The different levels of sulfur retention measured in the high ash, Indian coal and the high ash, co-fired, coal-biomass is one indication of the existence of other factors. The first step in clarifying these effects is to extend the test duration, which is planned for the next quarter. 


\section{RESULTS AND DISCUSSION}

\subsection{PROJECT DESCRIPTION}

\subsubsection{Objectives}

The primary project objective is to determine the degree of sulfur retention in slag in a full scale cyclone coal combustor. This non-equilibrium process is a key step in the capture and retention of sulfur released during coal combustion by the interaction with calcium based sorbent particles. By encapsulating the sulfur bearing calcium particles in slag, the need for landfilling of this waste is eliminated. This objective was to be implemented through a series of 16 one day tests carried out in a $20 \mathrm{MMBtu} / \mathrm{hr}$ air cooled, slagging combustor-boiler installation located in Philadelphia, PA. The project consists of two tasks. Task 1 consists of the experiments conducted in the $20 \mathrm{MMBtu} / \mathrm{hr}$ combustor, and task 2 consists of analysis of this data. All the operating procedures for this effort have been developed in the 10 years of operation of two designs of this combustor.

\subsubsection{Technical Approach}

\subsubsection{Overview of the Work}

The work of this project is being implemented on Coal Tech's patented, $20 \mathrm{MMBtu} / \mathrm{hr}$, air cooled cyclone coal combustor that is installed on an oil designed, package boiler at a new facility at the Arsenal Business Center in Philadelphia, PA. This new facility consists of a refurbished and upgraded $20 \mathrm{MMBtu} / \mathrm{hr}$ combustor that had been tested at a manufacturing plant in Williamsport, PA from 1987 through 1993. The primary fuel has been, and will remain, coal. Other tests, including combustion of refuse derived fuels and vitrification of fly ash, have been successfully

performed. It had originally been planned to add fly ash injection to achieve high sulfur retention in the slag in the present combustor tests. However, this option was eliminated because the bulk of the fly ash whose mean diameter is less than 10 microns is blown out of the combustor. Instead late in the project, very high (37\%) ash Indian coal and more recently, high ash biomass were used to achieve high slag flow rates.

The combustor's novel features are air-cooling and internal control of $\mathrm{SO}_{2}, \mathrm{NO}_{\mathrm{x}}$, and particulates. Air cooling, which regenerates the heat losses in the combustor, results in a higher efficiency and more compact combustor than similar water-cooled combustors. Internal control of pollutants is accomplished by creating a high swirl in the combustor. This traps most of the mineral matter injected in the combustor and converts it to a liquid slag that is removed from the floor of the combustor.

$\mathrm{SO}_{2}$ is controlled by injecting calcium oxide based sorbents into the combustor to react with sulfur emitted during combustion. The spent sorbent is dissolved in the slag and removed with it, thereby encapsulating the sulfur in slag. Part of the sorbent exits the combustor with the combustion products into the boiler where it can react with the sulfur. The primary objective of 
the present tests is to maximize the degree of sulfur retention in the slag. All spent sorbent not reporting to the slag is either deposited in the boiler or it is removed in the stack particle scrubber.

$\mathrm{NO}_{\mathrm{x}}$ is controlled by staged, fuel rich combustion inside the combustor. Additional reductions have been achieved by Coal Tech using post-combustion sorbent injection.

Excellent progress had been made prior to the start of the present project in meeting several of these combustor performance objectives. One of the most important objectives of this technology development effort is to demonstrate very high $\mathrm{SO}_{2}$ reduction in the combustor. Prior to the start of the present project, the peak $\mathrm{SO}_{2}$ reduction achieved with sorbent injection in the combustor had been $90 \%$. Of this amount a maximum of $11 \%$ of the total coal sulfur was trapped in the slag. Evaluation of this prior data indicated that the low sulfur retention in the slag was due to excessive slag residence time in the combustor. Since the solubility of sulfur in slag is low, long slag residence times (in excess of 5 minutes) can result in substantial sulfur gas re-evolution into the gas phase.

To reduce the slag residence time in the combustor in the present project tests, the slag mass flow rate must be increased to over $400 \mathrm{lb} / \mathrm{hr}$ by either using very high ash coals or by injection coal ash with the coal. High ash mass flow rates increase the slag flow rate.

In order to determine the non-equilibrium sulfur-slag chemistry, calcium sulfate (anhydrite) was injected into the combustor to vary the slag flow rate inside the combustor and to measure the sulfur gas evolution rate independently of the calcium-sulfur heterogeneous capture reaction. This information was used in subsequent tests to measure the combined sorbent-sulfur capture rate in the gas phase with the sulfur retention rate in the slag inside the combustor.

The 16 tests planned for this project were designed to allow full parametric variation of these sulfur-sorbent capture and sulfur-slag re-evolution reactions. Due to the complexity of these processes additional tests were required and implemented, all within the originally allocated project resources.

\subsubsection{Task Description}

\section{Task 1: Sulfur Chemistry Tests in the Slag of a Cyclone Combustor.}

This task was to consist of four groups of tests designed to validate the sulfur chemistry in slag under non-equilibrium conditions. The tests were designed to validate the chemical and fluid mechanical processes occurring in the capture and retention of sulfur in slag. These reactions are based on prior analytical and experimental work in coal slags and coal like slags, such as steel blast furnace slags. The original plan proposal for a total of 20 one-day tests. However, due to resource limitations, the plan was modified to accomplish the project objectives in as few as 16 one day tests. To meet all the parametric test variations, the duration of individual test conditions was reduced. However, the number of tests was increased substantially. As of the end of this reporting period, 12/31/97, 31 tests, 15 more than the planned 16 tests, have been completed and most of the technical issues related to this project have been identified. 
The original project plan was to perform first a group of six tests. Calcium sulfate as gypsum or plaster of Paris was to be injected into the $20 \mathrm{MMBtu} / \mathrm{hr}$ combustor at a rate that duplicates the complete reaction of sulfur from a $\mathbf{2 \%}$ sulfur coal with calcined calcium oxide particles. While maintaining this sulfur concentration fixed, the total slag mass flow rate was to be increased in discrete steps, with each step remaining fixed for a specific period. The purpose of these tests, and the second group of tests (described in the next paragraph), were to measure sulfur re-evolution from a sulfur based calcium compound at concentrations that duplicate the maximum amount of sulfur that can be captured in the combustor with calcium oxide sorbents.

In the second group of six tests, calcium sulfate was to be injected into the $20 \mathrm{MMBtu} / \mathrm{hr}$ combustor at a rate that duplicates the complete reaction of sulfur from a $4 \%$ sulfur coal with calcined calcium oxide particles. While maintaining this sulfur concentration fixed, the total slag mass flow rate was to be increased in discrete steps, with each step remaining fixed for a specific period.

These two groups of tests were to determine the sulfur retention capability of slag as a function of slag residence time in a commercial scale combustor, namely the unit rated at 20 $\mathrm{MMBtu} / \mathrm{hr}$. In other words, these tests focused only on the sulfur retention in slag. This type of test had been performed briefly in the previous $20 \mathrm{MMBtu} / \mathrm{hr}$ combustor facility in Williamsport, and the results indicated that this is an effective method for studying sulfur retention in slagging cyclone combustors.

As these tests were implemented, it was determined that high calcium sulfate levels in the slag sharply increased the slag viscosity to the point of severely inhibiting slag flow. The nature and number of these tests was modified, as is documented in Project Status Section of these Quarterly Progress reports.

In the third group of four tests, the entire sulfur capture process was to be implemented from the injection of the non-calcined sorbent to its reaction in the combustor and impact and removal with the slag. The slag mass flow rate was to be adjusted to duplicate the optimum slag flow rate determined from the group one tests. These fuel rich and fuel lean tests serve to validate the entire sulfur capture and retention process in the combustor.

In the final group of four one day tests, reacted sorbent collected in the boiler and stack baghouse was to be injected into the combustor at the optimum slag mass flow rate determined from the first two groups of tests. The objective of this test series was to determine the degree of sulfur encapsulation in slag in cases where the magnitude of sulfur capture with injection of sorbent in the combustor is insufficient to meet environmental emission standards.

All the experiments were to be conducted in accordance with the procedures developed in the seven years of testing in Williamsport and in the current tests in Philadelphia on the 20 $\mathrm{MMBtu} / \mathrm{hr}$ combustor. 
As the test effort proceeded the test plan was modified to account for the results of prior tests. The overall project objectives had been met as of the end of the 12/31/96 reporting period. Subsequent efforts were focused on operation with very high (over 30\%) ash coal where the high slag flow rate favors sulfur retention in slag. The benefit of high ash in the coal to the sulfur retention in slag was verified in the quarterly reporting period ending March 31, 1997 by using a $37 \%$ ash Indian coal. Here $20 \%$ of the injected sulfur was retained in the slag, which was double the previous record level measured by Coal Tech and others. A further test with this coal was implemented in the reporting period ending June 30, 1997. Here the sulfur retention level in the slag was only $5.8 \%$. The low level may have been due to the short test duration

\section{Task 2: Analysis}

The results of the tests are to be analyzed in this task. Part of the analytical models available for this purpose are two and three dimensional combustion codes for the conditions existing in this combustor, and a code for analyzing slag flow on the walls of the combustor. The results will be compared with prior tests in the present combustor and with laboratory scale data on the sulfur chemistry process in coal and steel slags. 


\subsection{PROJECT STATUS}

\subsubsection{Effort of the Present Quarter}

The implementation of the work on this project involves testing on Coal Tech's 20 MMBtu/hr slagging coal combustor-boiler test facility. A second-generation combustor was installed at a new facility in Philadelphia in 1995 and it became operational at the end of 1995. By the end of December 1997, a total of 103 days of tests were successfully implemented. Of this number, 31 tests were performed for the present project, of which 13 tests were implemented in the present quarterly reporting period, ending 12/31/97.

The objective of this project is to determine the degree of sulfur retention in slag in a full scale cyclone coal combustor with sulfur capture by calcium oxide sorbent injection into the combustor. This sulfur capture process consists of two steps: Capture of sulfur with calcined calcium oxide followed by impact of the reacted sulfur-calcium particles on the liquid slag lining the combustor. The sulfur bearing slag must be removed within several minutes from the combustor to prevent re-evolution of the sulfur from the slag. To accomplish this requires slag mass flow rates in the range of at least several $100 \mathrm{lb} / \mathrm{hr}$, preferably over $400 \mathrm{lb} / \mathrm{hr}$, or greater. To study this two step process in the combustor, two groups of tests have been implemented. In the first group, calcium sulfate in the form of gypsum or plaster of Paris was injected in the combustor to determine sulfur evolution from slag. In the second group, the entire process is tested with limestone and/or calcium hydrate injected into the combustor.

This original planned effort of up to 16 parametric tests in a $20 \mathrm{MMBtu} / \mathrm{hr}$ slagging, air cooled, cyclone combustor was completed in the quarter, ending March 31,1997. During the quarterly reporting period ending June 30,1997, three tests beyond the original plan for this project were implemented, bringing the total tests to 19 .

The reason for the extension of the test effort was that a supply of several tons of very high $(37 \%)$ Indian ash was obtained through DOE's Pittsburgh Operations in January 1997. In a pair of tests with this coal in January 1997 excellent results on sulfur retention were obtained with this coal. For the first time in the decade long operation of this combustor, a record $20 \%$ of the injected sulfur was retained in the slag at slag flow rates above $400 \mathrm{lb} / \mathrm{hr}$. It was, therefore, decided to extend the test effort with high ash coals.

During the previous quarterly reporting period ending June 30, 1997, 2 additional tests with this Indian coal were completed. However, in these latter tests only $5.8 \%$ of the sulfur injected into the combustor as gypsum reported to the slag. This was $1 / 4$ of the sulfur content measured with this Indian coal earlier in the project. No conclusive explanation for this difference was found. However, the test duration was limited to under one hour by the small amount of Indian coal available.

Consequently, the focus of the effort in the next quarter ending 9/30/97 was to obtain a source of very high ash (>30\%) coal. Contacts with a Brazilian and an Indian supplier yielded no response. A source of $30 \%$ ash coal from a Pennsylvania strip mine was found. However, it 
could not be pulverized due to the high shale content. Therefore, the focus in the present quarterly reporting period, ending 12/31/97, was shifted to co-firing bituminous coal was high ash biomass. As of the date of this report, a series of 13 biomass-coal tests have been successfully completed.

The use of biomass required a major modification to the feeding method into the combustor, which was designed for pulverized coal combustion. The coal is in powdered form and its density is about $35 \mathrm{lb} / \mathrm{cu}$.ft. The biomass, in this case rice husks, is in the form of small chips and its bulk density is only $7.5 \mathrm{lb} / \mathrm{cu}$.ft. In addition, tests were performed on co-firing coal with char-ash obtained as a residue from a rice husk gasifier. Its density is also only $15 \mathrm{lb} / \mathrm{cu}$.ft. Since the feed system available for the rice husk had a capacity rating of $1000 \mathrm{lb} / \mathrm{hr}$ for coal, and its rating is determined by the bulk density of the feed material, the capacity with rice husks would be $200 \mathrm{lb} / \mathrm{hr}$. Rice husks are somewhat unique among biomass materials in that they have a high ash concentration ranging from $15 \%$ to $20 \%$. Coal Tech's supply had a $15 \%$ ash content and a $\mathrm{HHV}$ of $6,500 \mathrm{Btu} / \mathrm{lb}$. When co-fired with a $10 \%$ ash coal at a nominal feed rate of $1,000 \mathrm{lb} / \mathrm{hr}$, $200 \mathrm{lb} / \mathrm{hr}$ rice husk feed rate would yield only a $130 \mathrm{lb} / \mathrm{hr}$ of ash injection. With the addition of about of a nominal 100 pounds of limestone for slag conditioning, the total injection rate of mineral matter would only be 186 pounds. This is much lower than the minimum desired 400 $\mathrm{lb} / \mathrm{hr}$ slag flow rate for high sulfur retention.

Consequently, the bulk of the effort in the 3 months ending 12/31/97 and in January 1998 was devoted to developing methods for increasing the biomass feed rate into the combustor. By using a series of innovative designs and procedures the capacity of the feed system was gradually increased from $200 \mathrm{lb} / \mathrm{hr}$ to $1,000 \mathrm{lb} / \mathrm{hr}$ during the first quarter of 1998 . This was accomplished by using the decade long experience acquired at Coal Tech in feeding pulverized coal, limestone, gypsum, and refuse derived fuel. By reusing previously expendable components, the expenditure for materials was kept to a minimum.

A supply of several tons of rice husks and rice husk char-ash was obtained from a rice mill. Initial testing began in October 1997 with five tests of about one-half day duration. The tests focused on developing means of feeding the extremely low-density biomass into the combustor. The rice husks were co-fired with coal or oil and it was found that the coal yielded superior combustion. Biomass firing rates gradually increased from $200 \mathrm{lb} / \mathrm{hr}$ to as high as almost 400 $\mathrm{lb} / \mathrm{hr}$ in the last tests. Since the test's objective was on increasing the feed rate, the rice husks were manually fed into the fuel-metering vessel. This limited the firing rate at any specific setting to less than one hour. Also, the feeding had to be periodically interrupted to clear out feed lines plugged with rice husks.

The last test in October was the first one in which any significant results were obtained. The test conditions were: Coal feed of $980 \mathrm{lb} / \mathrm{hr}$, with a HHV of 12,140 Btu/lb, $16.1 \%$ ash, and $2.29 \%$ sulfur. The rice husk feed rate was $393 \mathrm{lb} / \mathrm{hr}$. The total heat input was $15.15 \mathrm{MMBtu} / \mathrm{hr}$, including about $0.7 \mathrm{MMBtu} / \mathrm{hr}$ of propane. Excellent combustion and slagging results were obtained. Since rice husks feeding was manual there was insufficient time to collect operating data. 
The rice husk testing was continued in November with three runs of about one-half day duration using the $20 \mathrm{MMBtu} / \mathrm{hr}$ combustor in Philadelphia. They were performed on November 5,6 , and 13 . Biomass firing rates $400 \mathrm{lb} / \mathrm{hr}$ were routinely achieved, with brief periods of 480 $\mathrm{lb} / \mathrm{hr}$. The first two tests focused on using multiple injection ports with separate feeders. However, the port size into the combustor used for one feeder was too small to allow significant material flow, and the total feed rate remained below $500 \mathrm{lb} / \mathrm{hr}$.

Also, in the first test on November 5 another attempt was made to co-fire rice husks with oil only at a rate of 40 gallons/hr, or 5.6 MMBtu/hr. The rice husk feed rate was set at only 73 $\mathrm{lb} / \mathrm{hr}$. The stoichiometric ratio in the combustor, SR1, was set at 2 (i.e. 100\% excess air), and final combustion in the combustor exists was 2.8. Visual observation into the combustor indicated non-uniform combustion. As a result, the rice husk feed rate was not increased, and the test condition was terminated.

The next test on November $6^{\text {th }}$ was with same coal as in the October tests, at a $820 \mathrm{lb} / \mathrm{hr}$ feed rate. Two rice husk feed rates were co-fired with coal, $329 \mathrm{lb} / \mathrm{hr}$ and $400 \mathrm{lb} / \mathrm{hr}$. In addition, $150 \mathrm{lb} / \mathrm{hr}$ of limestone was injected for slag conditioning. Excellent combustion and slagging was observed for both conditions. SR1 was 1.2 and 1.1 for the two feed rates, and the total heat input was 12.8 and 13.8 MMBtu/hr. Additional air is added into the combustor exhaust to bring the final SR2 to 1.9 and 1.8 for the two conditions. The stack NOx at the outlet of the boiler was $0.6 \mathrm{lb} / \mathrm{MMBtu}$. This is in the lower end of the range measured for excess air conditions. No measurements of the stack $\mathrm{SO} 2$ were obtained.

The last test of November, on the $13^{\text {th }}$, was designed to test sulfur in slag retention by injecting gypsum with the coal and rice husk biomass and limestone. Only granular gypsum was readily available at that season of the year. The gypsum particle plugged the pneumatic feed line and the gypsum test was terminated after about 15 minutes of operation. A slag sample for this condition was taken and sent for analysis, but no sulfur was measured in the slag. Good stack gas samples for SO2 and NOx were obtained. With coal at $820 \mathrm{lb} / \mathrm{hr}$, rice husks at $400 \mathrm{lb} / \mathrm{hr}$, limestone at a $\mathrm{Ca} / \mathrm{S}$ of $1.39, \mathrm{SO} 2$ was $1.24 \mathrm{lb} / \mathrm{MMBtu}$. This is equal to a $67 \%$ reduction from the value one would obtain if all the coal sulfur is released as $\mathrm{SO} 2$.

The addition of the gypsum at a rate of $90 \mathrm{lb} / \mathrm{hr}$, added $14 \mathrm{lb} / \mathrm{hr}$ of sulfur to the $24 \mathrm{lb} / \mathrm{hr}$ of sulfur from the coal. This condition resulted in a measured SO2 at the stack of $1.88 \mathrm{lb} / \mathrm{MMBtu}$. This was still only $32 \%$ of the amount of sulfur that would have been converted to SO2 if all the sulfur in the coal and gypsum had evolved. This means that a substantial portion of the sulfur from the gypsum remained as solid or liquid CaSO4. The fact that it was not measured in the slag may have been due to the short test time. This would allow the CaSO4 to remain in the slag on the walls of the combustor and evolve gradually into the gas phase. The solution to this problem is to run very long tests with gypsum injection.

Overall, the three November tests continued to yield excellent slagging operation as the biomass feed rate was increase. Thus the conditions of high slag flow needed for sulfur retention appear achievable with the use of this biomass mass fuel. 
The test effort was continued in December with a further three runs of about one-half day duration. The tests again focused on further increasing the feed rate of the biomass into the combustor, and on sulfur retention in the slag from this material. The tests were performed in the $20 \mathrm{MMBtu} / \mathrm{hr}$ combustor facility in Philadelphia on December 10, 12, and 17.

In the test on December 10 , rice husk $(\mathrm{HHV}=6500 \mathrm{Btu} / \mathrm{lb})$ at a maximum rate of $310 \mathrm{lb} / \mathrm{hr}$ was co-fired with coal. To achieve an even higher slag flow rate, rice husk, char-ash at a maximum rate of $584 \mathrm{lb} / \mathrm{hr}$ subsequently co-fired with the coal at the same rate. This ash has a $\mathrm{HHV}$ of $3800 \mathrm{BTU} / \mathrm{lb}$. Both biomasses were co-fired with coal (HHV=13,600 Btu/lb) at 780 $\mathrm{lb} / \mathrm{hr}$ and $820 \mathrm{lb} / \mathrm{hr}$. Also, propane at $2 \mathrm{MMBtu} / \mathrm{hr}$ was added. In addition, gypsum at $150 \mathrm{lb} / \mathrm{hr}$ and limestone at $150 \mathrm{llb} / \mathrm{hr}$ were injected into the combustor. In this case, powdered gypsum was used, as opposed to granular gypsum in the November test. The total sulfur injected was $12 \mathrm{lb} / \mathrm{hr}$ from the coal and $24 \mathrm{lb} / \mathrm{hr}$ from the gypsum. Therefore, the injected ash from these fuels was 58 $\mathrm{lb} / \mathrm{hr}$ from the coal and $409 \mathrm{lb} / \mathrm{hr}$ from the rice husk ash. In addition, the calcium oxide from limestone and gypsum added $125 \mathrm{lb} / \mathrm{hr}$ of mineral matter. Thus a maximum of $592 \mathrm{lb} / \mathrm{hr}$ of mineral matter suitable for conversion to slag was injected. Since excellent slagging was observed, this very high mineral matter injection rate should have yielded high sulfur retention in the slag, especially when compared with earlier test results with the $37 \%$ ash, Indian coal. Nevertheless, the results of the analysis of several samples from this test yielded no sulfur in the slag. Again one explanation for this result is the short test duration. The rice-husk ash supply was such that less than 1 hour of total operation was possible.

However, another results that was different from the November test with gypsum injection was the very high degree of sulfur dioxide gas evolution when injecting the gypsum. Injecting the coal, rice husk,char-ash, and the limestone yielded a stack SO2 measurement of 1.65 $\mathrm{lb} / \mathrm{MMBtu}$. This was equal to about $86 \%$ of the total sulfur in the coal. When adding the gypsum at $150 \mathrm{lb} / \mathrm{hr}$, the stack SO2 increased the $6.11 \mathrm{lb} / \mathrm{MMBtu}$ in the initial set of readings, and decreased to $4.9 \mathrm{lb} / \mathrm{MMBtu}$ in a second set of readings. These two readings represented $120 \%$ and $98 \%$ of the total sulfur injected with the coal and the gypsum during the period of these two $\mathrm{SO} 2$ readings. It thus appears that all the sulfur in both the coal and in the gypsum was converted into the gas phase with no capture by the additional injected limestone. In all these test conditions, the SR1 in the combustor was 1.15 , i.e. excess air, a condition that produces a high combustion temperature and is not conducive to sulfur capture in the combustor. This may explain the high $\mathrm{SO} 2$ gas readings.

The test of the $12^{\text {th }}$ was performed as repeat of that part of the test of the $10^{\text {th }}$ with rice husk ash injection again at $584 \mathrm{lb} / \mathrm{hr}$. In this test, a different injection location for the rice husk ash was selected. Also, only gypsum at $150 \mathrm{lb} / \mathrm{hr}$ was injected. There was no limestone injection. Slagging was again excellent. However, again no sulfur was found in the slag. In this case, the test period with the rice husk ash was even shorter, less than $1 / 2$ hour, and the results are not conclusive.

The test of the $17^{\text {th }}$ was a brief test with a new rice husk feeding method. For a very brief period, a higher feed rate of rice husk was obtained. 


\section{CONCLUSIONS:}

The results of the 13 tests conducted in this quarterly reporting period were very significant.

One of the key objectives of the present project, namely achieving very high slag flow in the $20 \mathrm{MMBtu} / \mathrm{hr}$ combustor in order to retain sulfur in the slag, was achieved by using a high ash biomass. However, unlike the results in the high ash, Indian coal tests, no sulfur was measured in the slag with the injection of gypsum. One explanation for the test results of gypsum with biomass is the short test duration, which may have prevented steady state conditions from being achieved in the slag flow. However, this test duration was not significantly shorter that the one with the Indian coal. Therefore, other factors, such as the combustor's stoichiometric ratio, and/or the combustor gas temperature, and/or the physical or chemical state of the injected materials impact the degree of sulfur retention. Clearly, the first step in clarifying this matter is to conduct longer duration tests on co-firing coal with the rice husk biomass. An alternative option would be to conduct longer duration tests with very high ash coal. Additional tests with the biomass were implemented in the next quarter, $\left(1^{\text {st }}\right.$ quarter of 1998), and further increases in rice husk injection rates were achieved. However, the remaining project resources are insufficient to yield much further information on these processes.

The result of even greater significance in this reporting period was the development of methods for co-firing biomass with coal. This is of importance because it allows the use of the combustor as a device for mitigating greenhouse gas emissions by substituting high carbon coal with lower carbon renewable biomass.

Finally, a total of 13 tests in the $20 \mathrm{MMBtu} / \mathrm{hr}$ combustor have been implemented in the present quarterly reporting period for this project, bringing the total to 31 tests. This is double the 16 tests that were proposed in the original project plan for the resources allocated to this project. While the goal of complete sulfur capture and retention in the slag from coal combustion has not been achieved, the tests have achieved $20 \%$ sulfur retention in slag. This is double that measured previously in slagging combustors.

\subsection{EFFORT OF THE NEXT QUARTER}

In the next quarter the emphasis with the remaining project resources will be on further increasing the biomass feed rate into the combustor. The benefit of this approach is that the results apply not only to the present project objectives of sulfur retention in slag, but also to the general benefit of applying this combustor technology to co-firing coal with renewable biomass fuels which reduce greenhouse gas emissions. 